УДК 581.143

\title{
SEASONAL DISTRIBUTION OF PROCESSES RESPONSIBLE FOR RADIAL DIAMETER AND WALL THICKNESS OF SCOTS PINE TRACHEIDS
}

\author{
(C) 2015 G. F. Antonova, V. V. Stasova \\ $V$. N. Sukachev Institute of Forest, Russian Academy of Sciences, Siberian Branch \\ Akademgorodok, 50/28, Krasnoyarsk, 660036 Russian Federation \\ E-mail: antonova cell@mail.ru,roman@akadem.ru \\ Received 03.02.2015
}

\begin{abstract}
The timeframes of processes responsible for the number of cells, their radial diameters and wall thickness in annual wood increment of Scots pine in the course of season vegetation were studied. The number of cells produced by cambium, cell radial diameters in the cell growth expansion zone and the thickness/wall tracheid cross-sectional area in the secondary wall thickening zone were estimated at the transverse sections of samples taken from the stems in 10 days. The data obtained were used for the calculation of the development durations of tracheids in the zones of differentiation and the dependence of these characteristics of the processes on air temperature. Throughout the season, the processes of the production by cambium of early and late tracheids, their radial growth and secondary wall thickening occurs at different times and may overlap each with another in time. In the conditions of Middle Siberia (Russia), the production of cambium cells was observed in June and July. Radial diameter growth of earlywood tracheids occurred mainly in June, latewood tracheids - in July. The development of secondary wall thickening of earlywood cells occurred in June-July, latewood ones - in August to the first half of September. Hydrothermal conditions of these months affect considerably the morphological parameters of the tracheids. Each of the processes reacted to environmental factors independently and had their own optimum temperatures causing the differences in cell wall biomass deposited in separate periods of the season. The data should be considered in addressing the problem of productivity and quality of wood produced in different climate conditions.
\end{abstract}

Keywords: Scots pine (Pinus sylvestris L.), parameters of tracheids, processes of development, temperature impact.

How to cite: Antonova A. A., Stasova V. V. Seasonal distribution of processes responsible for radial diameter and wall thickness of Scots pine tracheids // Sibirskij Lesnoj Zurnal (Siberian Journal of Forest Science). 2015. N. 2: 33-40 (in English with Russian abstract).

To evaluate the influence of environmental factors on wood formation a mature xylem is used mainly. However in recent times there were analytical reviews, in which according to data on temperature in many regions of the last century a phenomenon called «divergence» between tree growth and climate factors has been reported, encompassing the divergence between tree growth and its main limiting climate factors as well as and the divergent growth responses of trees within study sites (Zhang Yong Wang et al., 2012). Authors underlined that it is essential to determine the physiological response mechanism of tree-ring growth to climate change. According to data collected over the period 1922-1991 years in France, the climatic models accounted for $46 \%, 37 \%$ and $42 \%$ of the variability of total ring, earlywood and latewood indices in dependence on monthly temperature and precipitation (Lebourgeois, 2000). Discussing the relationships between the timing of cambial reactivation, the start of xylem differentiation and changes in levels of storage materials in trees, the authors noted the need for better understanding of the mechanisms that regulate wood formation in trees, of the influence of environmental conditions on such mechanisms and understanding 
of the role of temperature in wood formation in trees (Begum et al., 2012).

Mature wood, consisting of layers of earlywood and latewood, formed during the season as the integral result of three processes: the production of cells by cambium, radial expansion and secondary wall thickening of cells. Two primary processes, responsible for the number of tracheids in radial row and their radial diameters, determine the width of annual wood ring. The former and latter processes account for practically all biomass, accumulated within cell walls of annual rings. All these processes are separated in space and, especially important, in time. The separate stages of wood formation can overlap each another in the time and weather conditions, which favourably affect one stage, can be unfavourable for other. Such phenomenon was observed in Larix sibirica Ldb. (Antonova and Stasova, 2002) and was explained by different internal events responsible for development of cells in the zones of differentiation. These findings are confirmed by the supposition that radial cell expansion and secondary wall thickening are under different physiological controls (Larson, 1960, 1964; Richardson, 1964; Wodzicki, 1971). Because of these complexities in the process of wood formation it is difficult to find real relationship between internal wood structure and environmental factors examining mature xylem only.

For the solution of the questions of environment influence on wood quantity and quality it is important to understand the distribution of the processes determining wood formation throughout the season.

The paper contains the data of seasonal distribution of the processes responsible for the formation of earlywood and latewood in the stems of Pinus sylvestris L. trees growing in Middle Siberia and of the effect of such important factor as temperature on these processes.

\section{MATERIALS AND METHODS}

The study was carried out in a natural stand located in forest-steppe of Siberia. This region is characterised by sharp continental climate. Duration of vegetable season is nearly 140 days.
The ten 50-60-year-old pine trees have been chosen by the average number of tracheids in radial rows of each of two proceeding seasons in each tree. These characteristics must be equal and must have normal distribution to ensure real reaction of the internal events within trees in the stand on the external factors. The trees with the reaction wood were eliminated. The average height of trees was $20 \mathrm{~m}$ and the average stem diameter was $18-19 \mathrm{~cm}$. The samples (one from each tree) were collected every 10 days beginning from May to September avoiding the effect of ringing. The sample has $0.8 \mathrm{~cm}$ and includes forming wood ring and the layers of two previous years. The cores were placed in formalinethanol-acetic acid (5:90:5) and kept before making the analysis. The cross-sections (two on each sample) were stained with $0.05 \%$ water solution of cresyl-violet what gives the special colors of cells with different development degree (Antonova and Shebeko, 1981a).

The number of cells within the zone of cambium, radial cell expansion and secondary wall thickening zone and mature cells as well as radial and tangential sizes of tracheids and their lumena in developmental zones along 8 radial rows were examined. All measurements were carried out with ocular micrometer with magnification 100-1000x. The standard errors of means of all measured and calculated parameters were not more than $5 \%$.

The data obtained have been used for calculating: 1) the thickness and cross-sections area of tracheid walls along radial row, 2) the duration of cell development in differentiation zones by Wodzicki method (Wodzicki, 1971), what we modified later (Antonova and Shebeko, 1981b). Temperature data were summarized for whole period of cell development in the zone. The data were used for computing of the mean day, mean maximum diurnal and mean minimum nocturnal temperatures. The effect of precipitation was estimated both the sum during development and the precipitation per day.

\section{RESULTS AND DISCUSSION}

After the beginning of cambium reactivation in May the first cells formed by cambium were phloem cells (Fig. 1). According to literature 


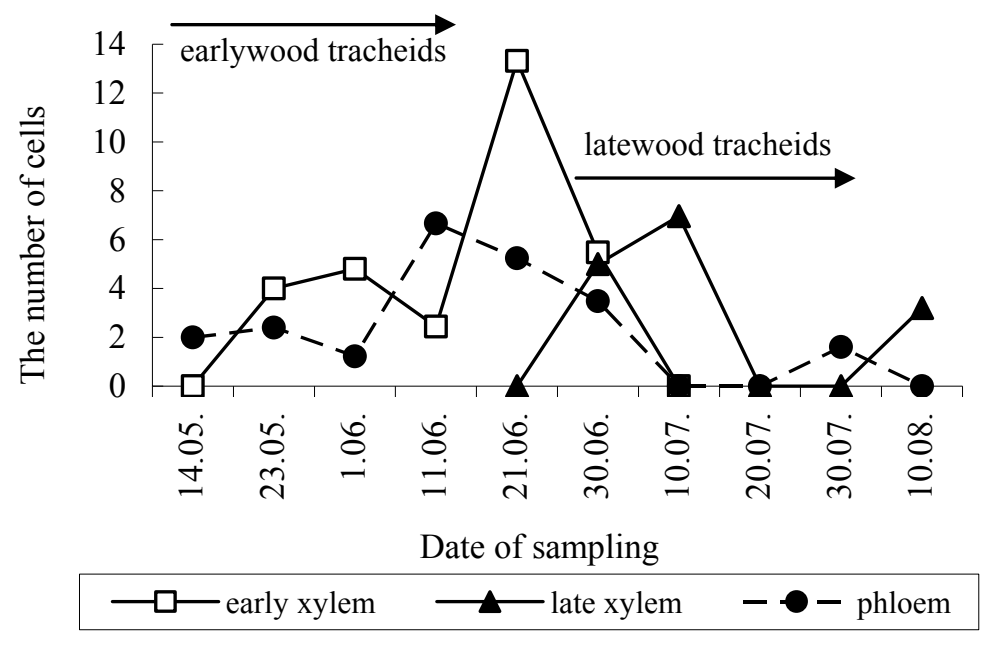

Fig. 1. The number of cells produced by cambium in separate periods of the season. Arrows show the duration of tracheid development.

data two or three layers of phloem elements are formed before xylem cells in Pinus strobus L. (Murmanis and Sachs, 1969) and Abies balsamea Mill (Kutscha et al., 1975). The appearance of sieve cells as first derivatives of cambium is functional necessity to provide the transport of photosynthetates. Xylem cells were produced by cambium in Scots pine stems 10 day later. In the conditions of Middle Siberia the production by cambium of phloem cells lasted from May to late August while of xylem cells from the late May to late July. In the first decade of June the cambium produced phloem cells more than xylem cells because of lower air temperature. Under lower temperature, the content of sucrose increases (Sauter, 1988) and high relation of sucrose/auxin stimulates of divisions of cambium initials to the side of phloem (Digby and Wareing, 1966; Jeffs and Northcote, 1967). In late June, the cambium formed the cells of both the early and late xylem. Initiation of latewood formation cells is an important moment in wood annual ring development. It occurs due to the changes in primary cell wall structure in the cambium zone (Fry, 1989) with the appearance of moisture deficit in developing tissue (Nonami and Boyer, 1990) as the result of external drought conditions (Larson, 1964; Zahner, 1963; Zahner et al., 1964; Brix, 1972) or exhausting of the moisture storage accumulated during winter-spring (Antonova and Stasova, 1993). Gregg et al. (1988) found that the latewood in loblolly pine (Pinus taeda) formed with decreased soil moisture content. In irrigated sites earlywood is produced later into growing season, whereas latewood formed earlier in the season under drought conditions (Zahner et al., 1964). The study of soil water deficit impact on growth and wood properties of larch, conducted in France, showed a strong negative effect on apical and radial growth as well as the timing of ring formation (Pâques, 2012). Water is one of the most important factors influencing the development of cells and their morphological parameters (Whitmore and Zahner, 1967). This is reflected in turn on the properties of the formed wood (Zobel and van Buijtenen, 1989), water transport and water storage in trees (Domec and Gartner, 2002). Water deficit has been found to change the content of carbohydrates and amino acids composition within the tissues of Scots pine and larch (Larix sibirica L.) (Sudachkova et al., 2002), the content and composition of phenolic compounds (Antonova et al., 2012), redox-potential of developing tissue (Antonova, 2012) and the trend of lignification during wood annual ring formation in Pinus sylvestris L. trees (Antonova et al., 2014).

Favorable environmental conditions of June contributed to the production of the greatest number of early tracheids by cambium in the second decade of the month (Fig. 1). Tracheids of both types were produced in late June and the greatest number of latewood cells appeared in the first decade of July. The development of earlywood tracheids lasted from Middle May to the end of July and of latewood ones - with the end of June to the first half of September. 


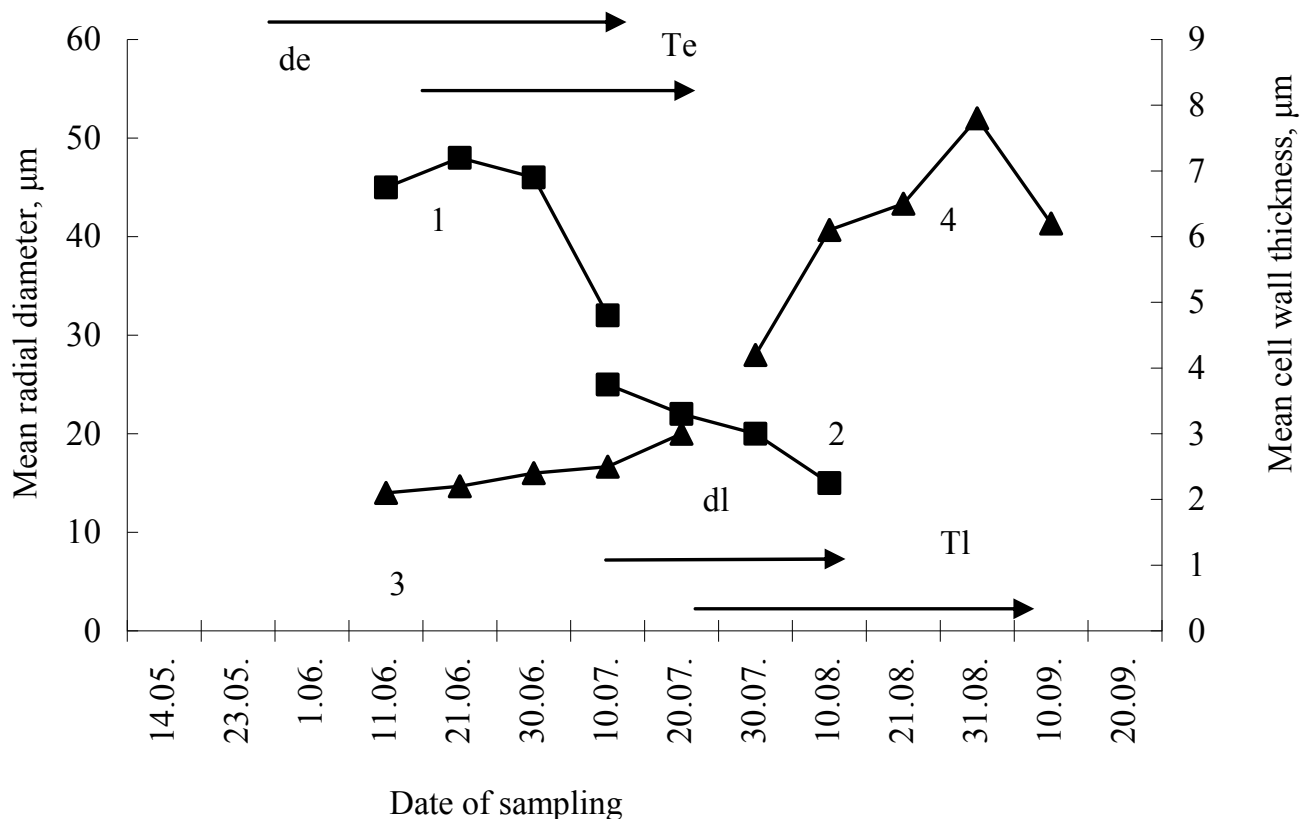

Fig. 2. Changes in mean radial diameters $(1,2)$ and in mean cell wall thickness $(3,4)$ of earlywood $(1,3)$ and latewood $(2,4)$ tracheids and the duration of development of radial diameters (de) and secondary wall thickening (Te) of earlywood cells and of radial diameters (dl) and secondary wall thickening (Tl) of latewood cells.

The optimal values of temperature and precipitation for tracheid development during annual wood ring formation in Pinus sylvestris L. stems

\begin{tabular}{l|c|c|c|c}
\hline \multirow{2}{*}{\begin{tabular}{c} 
Characteristics \\
\multicolumn{1}{c|}{ of annual wood ring formation }
\end{tabular}} & T mean daily & T max of day & T min of night & \multirow{2}{*}{ Precipitation, mm } \\
\cline { 2 - 4 }${ }^{\circ} \mathrm{C}$ & 24 & 9 & $3-4^{*}$ \\
\hline The number of cells in radial row & 20 & $27-28$ & $8-9$ & $15-20^{* *}$ \\
Radial diameter & $21-23$ & $20-21$ & 9 & $1,9-2,3^{* *}$
\end{tabular}

Foot-note. * - Precipitation in a 24 hour period, ** - Total precipitation during entire development period of tracheids in the zone.

In the limits of these periods the growth of early tracheid radial diameters (de) was mainly observed in June, of late ones (dl) - in July (Fig. 2). The development of secondary wall thickening of earlywood cells occurred in JuneJuly (Te), of latewood cells (Tl) - in August and in the first half of September. Thus after completion of production by the cambium of xylem cells the development of latewood tracheids continued more than month.

It is necessary remark that the similar distribution of the processes was observed in next season in the same stand for excluding the beginning of cell production by cambium because of unfavorable temperature conditions in May (Antonova and Stasova, 1993). But the time of earlywood-latewood transition was the same the late June. It is the rise in temperature in this time that stimulates the cell development as latewood tracheids.

Hydrothermal conditions of the months affect cell development on each stage by different ways. The each of processes reacts to the temperature and precipitation separately and has its own optimum temperature outside of which the activity of the process decreases (table).

So, the processes of cell production by cambium and radial cell expansion are similar in their temperature regimes, but sometimes they can be different in their temperature requirements as it was observed also in larch (Antonova and Stasova, 1997). At the same time, the optimum values of the air temperature and precipitation for the development of radial diameter and of cell wall cross-sectional area are considerably distinguished between each an- 


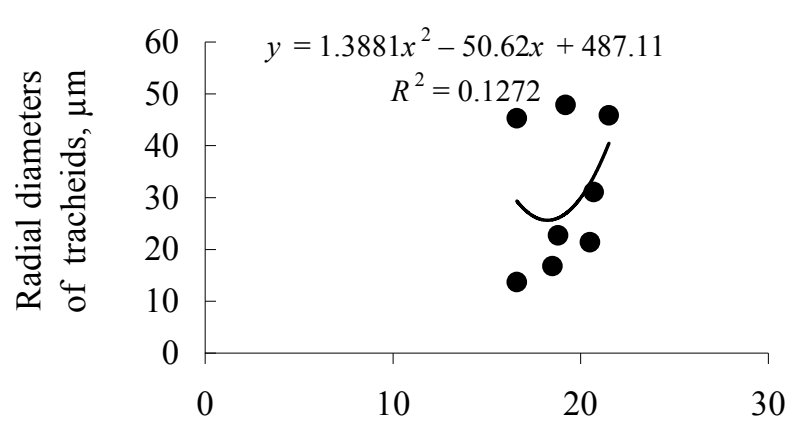

Mean daily temperature, ${ }^{\circ} \mathrm{C}$

Fig. 3. Dependence of tracheid radial diameter on mean daily temperature.

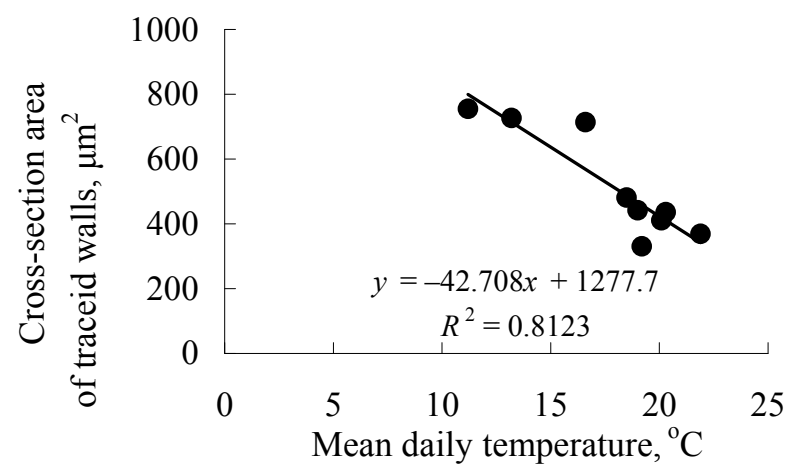

Fig. 4. Influence of mean daily temperature on crosssection area of tracheid walls $\left(\mu \mathrm{m}^{2}\right)$.

other what is resulted from different reactions of these processes on environmental factors.

For example, mean daily temperature influences positively radial growth (Fig. 3) and negatively cell wall cross-section area (Fig. 4). Such discrepancies are caused by the differences in internal physiological processes. The radial diameter of tracheids depends on their development rate in radial expansion zone and increased temperature contributes to the larger radial growth because with rising of temperature the rate of component synthesis increases.

Cell wall thickness (or cell wall cross-section area) depends on the time of presence of the tracheids in secondary wall thickening zone, i. e. the duration of development in the zone (Fig. 5), that is probably associated with transport processes of assimilates along radial row from phloem to developing cells. With increasing temperature the cell development duration is shortened (Fig. 6) because of a destruction of membranes within cells in connection with the

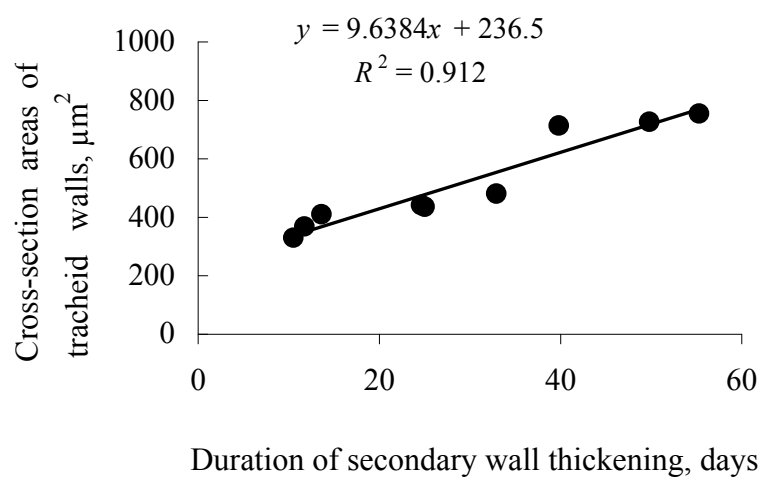

Fig. 5. Influence of cell development duration in secondary wall thickening zone on the cross-section area of tracheid walls.

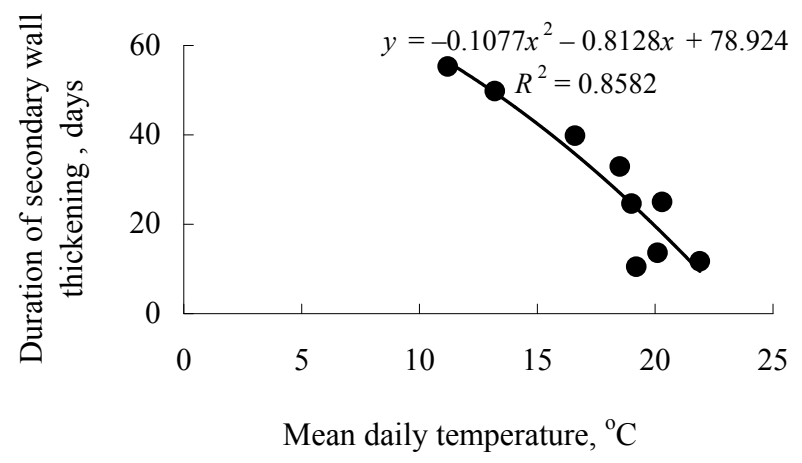

Fig. 6. Influence of mean daily air temperature at the time of pine tracheid development in secondary wall thickening zone.

intensification of hydrolyses under higher temperature. As the result the cross-section area of wall tracheids under high temperature is less than under lower temperature.

Different influence of temperature and precipitation at the separate stages of tracheid morphogenesis shows some independence of the stages taking part in the integral process of wood formation. This is resulted from the differences in physical and biochemical events, which are the base of each phase of cytogenesis (Antonova, 1999) and the reactions of these events to environmental factors.

We compared our data with the data from other countries. In Italy according to the xylogenesis observations in Larix decidua, Pinus cembra and Picea abies during 2001 year the cell production by cambium lasted from mid-May to the beginning of August, the first differentiating cells were observed at the end of May and the first latewood cells began wall thickening between July and August (Rossi et al., 2009). This practically coincides with our observation in 
Middle Siberia. In France the period of earlywood formation in Pinus nigra occurred mainly in early spring (May) whereas the growth of latewood layer was maximum in summer (July) (Lebourgeois, 2000). Interestingly, in these observations there is no data for September, while wall thickening of latewood tracheids lasted throughout August and to mid-September in Siberia and in such regions as Italy and France must be lasted even more, for example, during October and may be November.

In any case the overlapping of the development stages of earlywood and latewood tracheids throughout the season complicates significantly the study of the effect of environmental factors on wood formation, especially in stem. Of course, it should take into account the highly variable of climatic conditions in dependence on observation regions and sites. In these conditions such key points as the beginning and end of annual layer wood formation in the season will mainly vary but the internal physiological responses to environmental factors will be the same. The transition from early to latewood formation will vary within the limits of the end of June - beginning of July, because July is the warmest month, and the effect of temperature will be crucial, despite the presence of precipitation. In July, in the case of very wet conditions the emergence of the transition zone in annual wood increments should be expected. Reducing the temperature in August with sufficient rainfalls can lead to the formation of a false ring.

The results presented can promote the understanding of some physiological and biochemical events which resulted in the wood formation and be used to control the process in dependence on wood application.

\section{CONCLUSION}

The processes of cell production by cambium, of radial cell expansion and of secondary wall thickening occur in different time and can overlapped each another and weather conditions, which favourably affect one stage, can be unfavourable for other. The each of these processes reacts on environmental factors independently and has own optimum temperatures what is the cause of the differences in cell wall bio- mass deposited in separate periods of the season. The data contribute to the understanding of the physiology of wood formation and should be taken in consideration in the solution of the problem of productivity and quality of wood.

\section{REFERENCES}

Antonova G. F. Cell growth in conifers. Novosibirsk: Nauka. Sib. Publ. Firm. RAS, 1999. $231 \mathrm{p}$.

Antonova $G$. $F$. The role of ascorbate in growth and development of cells during the formation of annual rings in coniferous trees // Oxidative Stress in Plants: Causes, Consequences and Tolerance / Ed.: Naser A. Anjum, Shahid Umar, Altaf Ahmad). New Delhi - Bangalore: I.K. Int. Publ. House Pvt. Ltd., 2012. Chapt. 5. P. 443-466.

Antonova G. F., Shebeko V. V. Applying of cresylviolet in studying of wood formation // Chem. Wood (USSR). 1981a. N. 4. P. 102-105.

Antonova G. F., Shebeko $V$. V. Formation of xylem in conifers. 1. Seasonal dynamics determining the xylem formation in shoots of Larix sibirica Ldb. // Lesovedenie (Rus. J. For. Sci). 1981b. N. 5. P. 71-74.

Antonova G. F., Stasova $V . V$. Effects of environmental factors on wood formation in Scots pine stems // Trees. 1993. V. 7. N. 4. P. 214-219.

Antonova G. F., Stasova $V$. $V$. Effects of environmental factors on wood formation in larch (Larix sibirica Ldb.) stems // Trees. 1997. V. 11. N. 3. P. 462-468.

Antonova G. F., Stasova V. V. Seasonal distribution of processes responsible for radial diameter and wall thickness of larch (Larix sibirica Ldb.) tracheids // Proceedings of International Symposium «Improvement of larch (Larix sp.) for better growth, stem form and wood quality» Gap (Hautes-Alpes) Auvergne \& Limousin. France. 2002. Sept. 16-21. P. 369-377.

Antonova G. F., Varaksina T. N., Zheleznichenko T. V., Stasova V.V. Changes in phenolic acids during maturation and lignification of scots pine xylem // Rus. J. Developmental Biol. 2012. V. 43. N. 4. P. 250-260. DOI: $10.1134 / \mathrm{S} 1062360412040029$ 
Antonova G. F., Varaksina T. N., Zheleznichenko T. V., Stasova V. V. Lignin deposition during earlywood and latewood formation in Scots pine stems // Wood Sci. Technol. 2014. V. 48. N. 5. P. 919-936. DOI: 10.1007/ s00226-014-0650-3

Begum S., NakabaS., Yamagishi Y., Oribe Y., Funada $R$. Regulation of cambium activity in relation to environmental conditions: understanding the role of temperature in wood formation of trees // Physiologia Plantarum. 2012. 06. DOI: 10.1111/j.1399-3054.2012. 01663.x

Brix $H$. Nitrogen fertilization and water effects on photosynthesis and earlywood-latewood production in Douglas fir // Can. J. For. Sci. 1972. V. 2. P. 467-478.

Digby J., Wareing P.E. The effect of applied growth hormones on cambial division and the differentiation of the cambial derivatives // Ann. Bot. 1966. V. 30. N. 119. P. 118-200.

Domec J.-C., Gartner B. L. How do water transport and water storage differ in coniferous earlywood and latewood? // J. Exp. Bot. 2002. V. 53. N. 379. P. 2369-2379. DOI: $10.1093 / \mathrm{jxb} / \mathrm{erf} 100$

Fry S. C. The structure and functions of xyloglucan // J. Exp. Bot. 1989. V. 40. N. 1. P. 1-11.

Gregg B. M., Dougherty P. M., Hennessey T. C. Growth and wood quality of young loblolly pine trees in relation to stand density and climatic factors // Can. J. For. Res. 1988. V. 18. P. 851-858.

Jeffs R. A., Northcote D. H. The influence of indolacetic acid and sugar on the pattern of induced differentiation in plant tissue culture // J. Cell Sci. 1967. V. 2. N. 1. P. 77-87.

Kutscha N. P., HylandF., Schwarzmann J.M. Certain seasonal changes in Balsam fir cambium and its derivatives // Wood Sci. Technol. 1975. V. 9. N. 3. P. 175-188.

Larson P. R. A physiological consideration of the springwood-summerwood transition in red pine // For. Sci. 1960. V. 6. N. 1. P. 110-122.

Larson $P$. R. Some indirect effects of environment on wood formation // The formation of wood in forest trees / Ed. by M. H. Zimmermann. N. Y.: Acad. Press, 1964. P. 345-365.

Lebourgeois $F$. Climatic signals in earlywood, latewood and total ring width of Corsican pine from western France // Ann. For. Sci. 2000. 57 155-164. DOI: 10.1051/forest: 2000166

Murmanis L., Sachs J. B. Seasonal development of secondary xylem in Pinus strobus L. // Wood Sci. Technol. 1969. V. 3. N. 3. P. 177-193.

Nonami H., Boyer J.S. Wall extensibility and cell hydraulic conductivity decrease in enlarging stem tissues at low water potentials // Plant Physiol. 1990. V. 93. P. 1610-1619.

Pâques Luc E. Drought impact on growth and properties of larch // The 8th international symposium of IUFRO Working Group S2.02.07. Larix 2012: Larch in a warm climate. Hallormsstaðaskógur National Forest, Iceland, 11-13 September 2012. Abstracts. 20. Presentation. http://www.skogur.is/larix2012

Richardson S. D. The external environment and tracheid size in conifers // The formation of wood in forest trees / Ed. by M. H. Zimmermann. N. Y.: Acad. Press, 1964. P. 367-388.

Rossi S., Rathgeber C. B. K., Deslauriers A. Compararing needle and shoot henology with xylem development on three conifer species in Italy // Ann. For. Sci. 2009. 206. DOI: 10.105/forest/2008088.

Sauter J.J. Temperature-induced changes in starch and sugars in the stem of Populus $X$ canadensis «robusta»// Plant Physiol. 1988. V. 132. N. 5. P. 608-612.

Sudachkova N. E., Milyutina I. L., Semenova G. $P$. Influence of water deficit on contents of carbohydrates and nitrogenous compounds in Pinus sylvestris L. and Larix sibirica Ledeb. // Euras. J. For. Res. 2002. N. 4. P. 1-11.

Whitmore F. W., Zahner R. Evidence for a direct effect of water stress in tracheid cell wall metabolism in pine // For. Sci. 1967. V. 13. P. 397-400.

Wodzicki T. J. Photoperiodic control of natural growth substances and wood formation in larch (Larix decidua D. C.). // J. Exp. Bot. 1964. V. 15. N. 45. P. 584-599.

Wodzicki T. J. Mechanism of xylem differentiation in Pinus sylvestris L. // J. Exp. Bot. 1971. V. 22. N. 72. P. 671-687.

Zahner R. Internal moisture stress and wood formation in conifers // For. Prod. J. 1963. V. 13. P. 240-247. 
Zahner R., Lotan J. E., Baughman W. D. Earlywood-latewood features of red pine grown under simulated drought and irrigation // For. Sci. 1964. V. 10. N. 3. P. 361-370.

ZhangYong Wang, Bao Yang, Chun Qin, Feng Shi. Research progress in monitoring and simulating stem radius growth: an overview //
Sci. in Cold and Arid Regions. 2012. V. 4(2).

P. 0175-0183. DOI: 10.3724/SP.J.1226. 2012.00175

Zobel D. J., van Buijtenen J. P. Wood variation // Ed. by T. E. Timell. Berlin, Heidelberg, N. Y., L., Paris, Tokyo: Springer-Verlag, 1989. $365 \mathrm{p}$.

\title{
СЕЗОННОЕ РАСПРЕДЕЛЕНИЕ ПРОЦЕССОВ, ОТВЕТСТВЕННЫХ ЗА РАДИАЛЬНЫЙ ДИАМЕТР И ТОЛЩИНУ СТЕНОК ТРАХЕИД СОСНЫ ОБЫКНОВЕННОЙ
}

\author{
(C) 2015 г. $\quad$ Г. Ф. Антонова, В. В. Стасова \\ Институт леса им. В. Н. Сукачева СО РАН \\ 660036, Красноярск, Академгородок, 50/28 \\ E-mail: antonova_cell@mail.ru,roman@akadem.ru \\ Поступила в редакцию 03.02.2015 г.
}

Изучали временные рамки процессов, ответственных за число клеток, их радиальный диаметр и толщину стенки трахеид в годичном приросте древесины сосны обыкновенной в ходе вегетационного периода. На поперечных срезах образцов, которые брали из стволов через каждые 10 дней, определяли число клеток, образованных камбием, измеряли радиальные размеры клеток в зоне роста клеток расширением и толщину/площадь поперечного сечения стенок трахеид в зоне развития вторичной стенки. Полученные данные использовали для расчета продолжительности развития клеток в зонах развития и зависимости показателей процессов от температуры воздуха. Показано, что процессы производства камбием ранних и поздних трахеид, их радиального роста и утолщения вторичной стенки происходят в ходе сезона в разное время и могут перекрывать друг друга во времени. В условиях Средней Сибири производство клеток камбием наблюдалось в июне и июле. Рост радиального диаметра трахеид ранней древесины проходил главным образом в июне, поздней - в июле. Развитие утолщения вторичных стенок ранних трахеид идет в июне-июле, тогда как поздних - в августе-первой половине сентября. Гидротермические условия этих месяцев значительно влияют на морфологические параметры трахеид. Каждый из процессов реагирует на факторы внешней среды независимо и имеет свои собственные оптимальные температуры, что является причиной различий в биомассе клеточных стенок, развивавшихся в отдельные периоды сезона. Данные следует принимать во внимание при рассмотрении вопросов по проблеме продуктивности и качества древесины, продуцированной в различных климатических условиях.

Ключевые слова: сосна обыкновенная (Pinus sylvestris L.), nараметры трахеид, процессы развития, влияние температуры.

DOI: $10.15372 / S J F S 20150203$ 